\title{
Analysis of Factors Influencing Access to Formal Loan Among Small-scale Swamp Rice Farmers in Obubra Local Government Area, Cross River State, Nigeria
}

\author{
Kuye Olufemi Oludayo*, Ogiri Oyom Mbina \\ Department of Agricultural Economics and Extension, Faculty of Agriculture and Forestry, Cross River University of Technology, Obubra \\ Campus, Obubra, Nigeria
}

Email address:

dayokuye@yahoo.com (K. O. Oludayo)

${ }^{*}$ Corresponding author

\section{To cite this article:}

Kuye Olufemi Oludayo, Ogiri Oyom Mbina. Analysis of Factors Influencing Access to Formal Loan Among Small-scale Swamp Rice Farmers in Obubra Local Government Area, Cross River State, Nigeria. International Journal of Agricultural Economics.

Vol. 4, No. 6, 2019, pp. 307-313. doi: 10.11648/j.ijae.20190406.19

Received: December 23, 2019; Accepted: January 3, 2020; Published: January 17, 2020

\begin{abstract}
This study analyzed the factors influencing access to formal agricultural loan among small-scale swamp rice farmers in Obubra Local Government Area in Cross River State, Nigeria. Data were obtained from 120 respondents by using multi-stage random sampling technique. Descriptive statistics and logit regression model were used to analyze the data. The results showed that majority (62.5\%) of the farmers were males, about 40\% were aged between $31-40$ years, married (68.33\%), had household size of 7-9 persons (51.67\%), had secondary education $(51.67 \%)$, had farm sizes of $1-2 \mathrm{ha}(50.83 \%)$, had farming experiences of $11-20$ years (45\%) and only 30.83\% had annual farm income of between $\$ 51,000.00$ and $\$ 100,000.00$. The logit regression analysis revealed that gender, farm income, household size, education and collateral positively influenced the probability of farmers' access to loan at $1 \%$ significant level respectively. Marital status, farming experience and farm size positively influenced access to loan at $5 \%, 5 \%$ and $10 \%$ respectively The major constraints respondents faced in accessing loan are long period of processing loan applications, problem of getting collateral and high interest rate while the major constraints they faced in rice production are crop destruction by cattle, low yield as a result of pests and diseases and low yield as a result of poor soil. The Federal Government should enact law that will motivate the cattle herders to compensate any farmer whose crops have been destroyed or eaten by their cattle and banks should process loan applications on time so that the loan will be disbursed to farmers at the appropriate time.
\end{abstract}

Keywords: Analysis, Factors, Access, Formal, Loan, Swamp Rice

\section{Introduction}

One of the major problems confronting small and mediumscale farmers in Nigeria is poor access to cheap, affordable and adequate credit. In Nigeria, the small-scale farmers produce the bulk of the domestic agricultural output Adeyonu, Ajiboye, Isitor and Faseyi [1]. Access to credit is regarded as one of the key elements in raising agricultural productivity [2]. Availability of adequate and timely credit help in expanding the scope of operation and adoption of new technologies, enhance the purchase and use of improved inputs and facilitate other up-stream and down-stream operations in agriculture [3]. Most farm households depend on credit because credit provides cash reserves required to invigorate the process of production and consumption in the next production season. The development process of the agricultural sector can be enhanced by the ease with which credit is obtained by farmers. To the average farmer, credit provides a means of transfer of assets and wealth or allows him access to the use of these [4].

According to [4] the main function of credit in smallholder farming is that it opens greater opportunities for the acquisition of inputs. Through this way credit could effectively function to overcome agricultural stagnation in developing countries. The term agricultural credit according to [5] includes all cash advances to farmers and service production activities relating to agriculture. It is a vehicle for improving agricultural technology. 
Agricultural credit can also be referred to as loans extended to farmers for production, storage, processing and marketing of farm products. It is one of the fundamental ingredients of sustainable agricultural production, as such, its accessibility and demand is among the pre-requisites for attaining the national goal of reducing rural poverty and ensuring self-food sufficiency in the country $[6,7]$. Such credit can be short, medium or long term depending on its duration. Credit institutions range from well-developed and large-sized commercial banks to localized small cooperatives. It can also be formal or informal.

According to [8], a household is said to have access if it is able to borrow from a credit source (commercial banks, cooperative societies, money lenders, and so on). The extent of access to credit is measured by the maximum amount a household can borrow at a time from a given source. According to [9], access to agricultural micro-credit remains a critical challenge to smallholder farmers in many developing countries including Nigeria. This is because smallholder farmers often require small loans which are difficult to administer while majority of them also lack the needed collateral to be able to borrow from formal sources. Where collateral requirements are met, the small size of potential borrowers always seems to exclude others from borrowing. Consequently, smallholder farmers have been marginal participants in the credit market in many developing countries. As noted by [10], access to credit is the topmost priority of smallholder farmers in Nigeria where agriculture is the main economic activity.

The agricultural sector is dominated by small-scale farmers in Nigeria. They engage in subsistence agriculture. They accounted for more than $90 \%$ of the nation's agricultural output. They cultivate less than 2 ha of farmland [11]. According to [12], the agricultural sector is characterized by preponderance of small-holder farmers and their families, who produce about 90 percent of the staple food requirements of the ever-increasing population. They play a very important role in promoting the nation's economic growth and development. These small-scale farmers are sinking deeper and deeper into poverty, especially in sub-Saharan Africa and now account for three quarter of the world-poor. Promoting the growth of this sector is the most effective way to fight poverty [13-15, 4]. Furthermore, Nigerian farmers face huge challenges in accessing farm credit, farm inputs and marketing their products. They are trapped in a vicious cycle of poverty as a result of low productivity $[16,4]$. In order to remove these challenges, farmers should be provided financial support to expand their production level.

Rice (Oryza sativa) is one of the major food crops produced by Nigerian farmers. It is the most important cereal in the world with and a source of prime income to small-scale farmers in Nigeria. Most rice farmers in Nigeria are smallscale farmers faced with enormous difficulties in accessing loan facilities due to inadequate bank branches, late disbursement of agricultural loans, collateral requirements, filling of many forms, diversion of agricultural loans by the banks' staff for non-agricultural purposes and inability of the banks to reach small-scale farmers at the grassroots [4].
Ugbajah and Ugwumba [17] asserted that one of the problems confronting small-scale farmers in Nigeria is inadequate capital. Evidence has shown that inadequate capital and/or lack of access to credit has been a major problem to small-scale and/or poor farmers [18]. According to [17] efforts made by the rural farmers to get financial assistance are always constrained by unnecessary strings attached to the credit services, especially collaterals used for assessing the borrower's credit worthiness; delay in release of loan and unfavourable repayment terms for agricultural based activities by commercial banks [19]. This study specifically, therefore, identified the socio-economic characteristics of farmers, assess the extent of loan accessibility among the farmers, analyze the influence of socio-economic factors on credit accessibility among the farmers and identify the constraints faced by farmers in accessing loan and constraints faced in swamp rice production in Obubra Local Govern Area.

\section{Methodology}

\subsection{Study Area}

The study was conducted in Obubra Local Government Area of Cross River State. Obubra is located in the Central Senatorial District of Cross River State and lies between longitude $7^{\circ} 55^{\prime} \mathrm{E}$ and $8^{\circ} 10^{\prime} \mathrm{E}$ of the Greenwich Meridian and latitude $5^{\circ} 4^{\prime} \mathrm{E}$ and $6^{\circ} 10^{\prime} \mathrm{N}$ of the equator. It has a population of 134,255 people and occupies a land mass of $1,086 \mathrm{~km}^{2}$ [20]. Obubra is made up of eleven council wards and three clans namely; Adun, Osopong and Okum.

The inhabitants are predominantly farmers. The major crops they grow are swamp rice, cassava, and yam though they grow other crops like sugarcane, sweet potato, vegetables, oil palm, oranges, plantain, banana and cocoa. The farmers particularly grow swamp rice because they are blessed with abundant swampy areas. They rear animals like sheep, goat, pig and poultry birds and engage in fishing because of the passage of Cross River which stretches across the Local Government Area.

\subsection{Sampling Technique}

Multi-stage random sampling technique was employed to select small-scale swamp rice farmers during the 2016/2017 farming season. The first stage involved random selection of three villages from each of the three clans giving a total number of nine (9) villages. The villages were: Ovonum, Ofodua, Ofatura, Apiapum, Ohana, Ochon, Ofunbongha 1, Ofunbongha 11 and Ogurude. The second stage involved random selection of 154 swamp rice farmers proportionate to size from a list of 770 swamp rice farmers from the nine villages. The list of swamp rice farmers was obtained from the ADP Extension office in the Local Government Area. Only 120 respondents provided meaningful information that was used for analysis.

\subsection{Data Analysis}

Data gathered on socio-economic characteristics of 
farmers, extent of access to loan, constraints faced by farmers in accessing loan and constrained faced by farmers in swamp rice production were analyzed using simple descriptive statistic. Logit regression model was used to analyze the factors influencing access to loan among farmers. The logit regression model is explicitly expressed as follows:

$$
\ln Y\left[\frac{P_{i}}{1-P i}\right]=\mathrm{Zi}=\beta_{0}+\beta_{1} X_{1}+\beta_{2} X_{2}+\beta_{3} X_{3}+\beta_{4} X_{4}+\beta_{5} X_{5}+-------U_{i}
$$

Where,

$\mathrm{Y}=$ is a binary variable defined as 1 if a farmer has access to loan and 0 if otherwise

$\mathrm{Pi}=$ Probability of access to loan (1)

$1-\mathrm{Pi}=$ no access to loan $(0)$

$\mathrm{Ln}=$ Natural logarithm function

$\mathrm{Zi}=\log$ of odds

$\mathrm{X}_{1}=$ gender $($ male $=1$, female $=0)$

$\mathrm{X}_{2}=$ age of household head (years)

$\mathrm{X}_{3}=$ Marital status (married $=1$, single $=0$ )

$\mathrm{X}_{4}=$ Farm income $(\mathbb{N})$

$\mathrm{X}_{5}=$ Household size (Number)

$\mathrm{X}_{6}=$ Education level (years)

$\mathrm{X}_{7}=$ Farm size (ha)

$\mathrm{X}_{8}=$ Presence of collateral $(\mathrm{yes}=1$, no $=0$ )

$\mathrm{X}_{9}=$ Farming experience (years)

$\mathrm{U}_{\mathrm{t}}=$ error term

$\beta_{\mathrm{i}}, \beta_{2} \ldots \ldots \beta_{\mathrm{i} \text { th }}$ are coefficients.

\subsection{Hypothesis Testing}

A single null hypothesis was formulated and tested to guide the research major objective.

$\mathrm{H}_{\mathrm{O}}$ : Some socio-economic factors do not have significant effect on access to loan by rice farmers. Chi-square $\left(\mathrm{X}^{2}\right)$ was used to test the hypothesis.

\section{Results and Discussion}

\subsection{Socio-economic Characteristics of Respondents}

The socio-economic and demographic profiles of the respondents presented in Table 1 indicate that most of the swamp rice farmers (62.5\%) were males, $40 \%$ were aged between 31 and 40 years and 68\% were married. Majority (51\%) had between 4-6 persons in their households and attended secondary schools (51\%). About 51\% cultivated between 1 and 2 ha, $45 \%$ had $11-20$ years of farming experience with about $31 \%$ having between $\$ 50,000-\$ 100,000$ annual farm income. Majority $68 \%$ belonged to cooperative societies. From the foregoing analysis, it can be inferred that the sampled farmers generally were small-scale farmers, fall within the active farming age and with long years of farming experience. However, because majority were married with large household size and low annual income they need to gain access to adequate loan facility. This could help improve their farm output, farm income and living standard. These results also indicate that since majority were married they are likely to incur more expenditure on family upkeep from the loan facility. This result is in harmony with the study carried out by [21] who reported that married farmers would incur extra expenditures for family livelihood from the loan given to them, thereby threatening their ability to repay the loan. More so, since they are smallholder farmers they may have difficulty in getting access to adequate loan from formal sources because of the small nature of their farming and inability to meet the collateral requirement. This is in agreement with the findings of [4] who asserted that banks prefer giving loan to medium and large scale farmers because of high management cost on micro loans.

Table 1. Socio-economic characteristics of respondents.

\begin{tabular}{|c|c|c|}
\hline Variable & Frequency $(n=120)$ & Percentage (\%) \\
\hline \multicolumn{3}{|l|}{ Gender } \\
\hline Male & 75 & 62.5 \\
\hline Female & 45 & 37.5 \\
\hline \multicolumn{3}{|l|}{ Age (yr) } \\
\hline $21-30$ years & 12 & 10.00 \\
\hline $31-40$ years & 48 & 40.00 \\
\hline $41-50$ years & 37 & 30.83 \\
\hline $51-60$ years & 18 & 15.00 \\
\hline Above 60 years & 5 & 4.17 \\
\hline \multicolumn{3}{|l|}{ Marital status } \\
\hline Single & 18 & 15.00 \\
\hline Married & 82 & 68.33 \\
\hline Divorced & 20 & 16.67 \\
\hline \multicolumn{3}{|l|}{ Household size } \\
\hline $1-6$ persons & 48 & 40.00 \\
\hline $7-9$ persons & 62 & 51.67 \\
\hline 10 persons and above & 10 & 8.33 \\
\hline \multicolumn{3}{|l|}{ Education level (yr) } \\
\hline Never attended school & 11 & 9.17 \\
\hline Primary education & 29 & 24.16 \\
\hline Secondary education & 62 & 51.67 \\
\hline Higher education & 18 & 15.00 \\
\hline \multicolumn{3}{|l|}{ Farm size (ha) } \\
\hline Less than 1 ha & 28 & 23.34 \\
\hline $1-2$ ha & 61 & 50.83 \\
\hline Above 2 ha & 31 & 25.83 \\
\hline \multicolumn{3}{|l|}{ Farming experience (yr) } \\
\hline $1-10$ years & 36 & 30.00 \\
\hline $11-20$ years & 54 & 45.00 \\
\hline Above 20 years & 30 & 25.00 \\
\hline \multicolumn{3}{|l|}{ Annual income ( } \\
\hline Less than $¥ 50,000$ & 13 & 10.83 \\
\hline$\$ 51,000-\$ 100,000$ & 37 & 30.83 \\
\hline$\$ 101,000-\$ 150,000$ & 35 & 29.17 \\
\hline$\$ 151,000-\$ 200,000$ & 21 & 17.5 \\
\hline Above $\$ 200,000$ & 14 & 11.67 \\
\hline \multicolumn{3}{|l|}{ Other crops planted } \\
\hline Cassava & 39 & 32.50 \\
\hline Yam & 41 & 34.17 \\
\hline Maize & 21 & 17.50 \\
\hline Vegetables & 19 & 15.83 \\
\hline \multicolumn{3}{|c|}{ Membership of cooperative } \\
\hline Yes & 82 & 68.33 \\
\hline \multicolumn{3}{|l|}{ Presence of collateral } \\
\hline Yes & 89 & 74,16 \\
\hline
\end{tabular}

Source: Field data, 2017. 


\subsection{Extent of Access to Loan by Respondents}

As contained in Table 2, majority of the respondents (40\%) applied for relatively large amounts above $\$ 200,000.00$ but only $8 \%$ received loans above N200,000.00. About $42 \%$ of the respondents received $\$ 100,000.00$. However, the average values of loan applied and received were $\$ 169,583.33$ and
$\$ 103,333.33$. This result implies that the amount of loan received was lower to the amount applied by $\$ 66,250.00$. This finding is in consonant with the work of [22] who found a significant difference between the mean of loan supplied and mean of loan demanded among arable crop farmers in Benue state.

Table 2. Distribution of respondents according to amount of loan applied and received.

\begin{tabular}{llllc}
\hline \multirow{2}{*}{ Size of loan (N) } & Amount Applied & & \multicolumn{2}{c}{ Amount Received } \\
\cline { 2 - 5 } & Frequency & \% & Frequency \\
\hline$<50,000$ & & - & 50 & - \\
$51,000-100,000$ & 24 & 20 & 42 & 41.67 \\
$101,000-150,000$ & 25 & 20.83 & 35 & 18 \\
$151,000-200,000$ & 23 & 19.17 & 10 & 8.33 \\
$>200,000$ & 48 & 40 & 10 & 100 \\
Total & 120 & 100 & 10 & \\
\hline
\end{tabular}

Source: Field data, 2017.

\subsection{Factors Influencing Access to Loan by Respondents}

Table 3 presents the logit regression results of the socio-economic factors influencing rice farmers' access to formal loan in the study area.

Table 3. Logit Regression Results of Factors Influencing Access to Loan.

\begin{tabular}{lllll}
\hline Variables & Coefficient & Standard error & Wald coeff. & Exponential \\
\hline Constant & 37.157 & 0.140 & 1.252 & 0.855 \\
Gender $\left(\mathrm{X}_{1}\right)$ & $5.404^{* * *}$ & 0.040 & 2.354 & 0.765 \\
Age $\left(\mathrm{X}_{2}\right)$ & $-5.864^{* *}$ & 0.349 & -0.908 & 0.876 \\
Marital status $\left(\mathrm{X}_{3}\right)$ & $3.345^{* *}$ & 0.234 & 1.342 & 0.234 \\
Farm income $\left(\mathrm{X}_{4}\right)$ & $6.543^{* * *}$ & 12.453 & 1.311 & 0.345 \\
Household size $\left(\mathrm{X}_{5}\right)$ & $1.647^{* * *}$ & 2.345 & 0.456 & 0.234 \\
Educational level $\left(\mathrm{X}_{6}\right)$ & $4.127^{* * *}$ & 0.989 & 0.289 & 0.134 \\
Farm size $\left(\mathrm{X}_{7}\right)$ & $18.619^{*}$ & 2.568 & 0.976 & 1.234 \\
Presence of collateral $\left(\mathrm{X}_{8}\right)$ & $21.651^{* * *}$ & 3.456 & 3.876 & 0.235 \\
Farming experience $\left(\mathrm{X}_{9}\right)$ & $13.111^{* *}$ & 0.999 & -2.111 & 2.560 \\
Cox \& Snell $\mathrm{R}^{2}$ & 0.712 & & & \\
Nagelkerke (adjusted $\mathrm{R}^{2)}$ & 0.843 & & & \\
Log-likelihood test & 0.002 & & & \\
Chi-square & $165.654^{*}$ & & & \\
\hline
\end{tabular}

Source: Field data, 2017.

$*, * *$ and ${ }^{* * *}$ are significant at $10 \%, 5 \%$ and $1 \%$ levels of probability respectively.

The Cox \& Snell $\mathrm{R}^{2}$ value of 0.712 indicates that $71 \%$ of the probability of farmers to access loan is explained by the explanatory variables used in the logit model. The Nagelkerke R square (adjusted $\mathrm{R}^{2}$ ) was 0.843 , indicating a strong relationship of $84.3 \%$ between socio-economic characteristics of the respondents and access to loan.

The value of chi-square (165.654) revealed that the model was significant at $10 \%$ level. This indicates that the respondents socio-economic characteristics considered in the model are relevant in influencing loan acquisition. Hence, the null hypothesis was rejected and the alternative hypothesis accepted.

Results of the logit model show that gender $\left(\mathrm{X}_{1}\right)$, farm income $\left(\mathrm{X}_{4}\right)$, household size $\left(\mathrm{X}_{5}\right)$, education $\left(\mathrm{X}_{6}\right)$ and collateral $\left(\mathrm{X}_{8}\right)$ positively increased the likelihood of farmers' access to loan at $1 \%$ significant level respectively.
Furthermore, marital status $\left(\mathrm{X}_{3}\right)$, farming experience $\left(\mathrm{X}_{9}\right)$ and farm size $\left(\mathrm{X}_{7}\right)$ positively influence access to loan at $5 \%, 5 \%$ and $10 \%$ respectively while age $\left(\mathrm{X}_{2}\right)$ of farmers negatively influence access to loan at 5\% significant level. This shows that access to loan decline with age. This means that as age increases, farmers experienced decline in their physical strength and would likely become less enthusiastic to continue in farming contrary to when they were young and energetic. This would discourage any interest in increasing production level and definitely reduce the probability to access loan. This result agrees with the findings of [9] who asserted that age of farmers negatively impacted access to loan.

The positive coefficient of gender $\left(\mathrm{X}_{1}\right)$ that was significant at $1 \%$ meant that there was a higher probability that both male and female farmers had greater chances of accessing 
loan. Farm income $\left(\mathrm{X}_{4}\right)$ positively and significantly influenced the chances of farmers' access to loan. Increase in farm income may build the lenders confidence on the farmers capacity to repay anticipated loans. This result is further corroborated by the findings of [23] who revealed that farm income had a significant and positive influence on smallscale rice farmers' in loan acquisition in Benue State, Nigeria. They inferred that farm income is a strong indication for high productivity which can significantly boost the zeal of farmers' in loan acquisition. The coefficients of other explanatory variables like marital status $\left(\mathrm{X}_{3}\right)$, household size $\left(\mathrm{X}_{5}\right)$, education $\left(\mathrm{X}_{6}\right)$, farm size $\left(\mathrm{X}_{7}\right)$, presence of collateral $\left(\mathrm{X}_{8}\right)$ and farming experience $\left(\mathrm{X}_{9}\right)$ that are positive and significant imply that increase in these variables would increase the chances of farmers' access to loan. This will invariably lead to increase in the farmers' output. This result is concordant to the findings of [24] who asserted that farm size, farming experience and farm income had positive influence on the probability of accessing formal credit among small-scale farmers in Kogi State, Nigeria.

\subsection{Constraints Rice Farmers Faced in Accessing Loan}

Table 4 presents the findings on the constraint rice farmers faced in accessing loan in the study area.

Table 4. Constraints rice farmers faced in accessing loan.

\begin{tabular}{|c|c|c|c|c|}
\hline \multirow{2}{*}{$\mathbf{S} / \mathbf{N}$} & \multirow{2}{*}{ Constraints } & \multicolumn{2}{|l|}{ Yes } & \multirow{2}{*}{ Rank } \\
\hline & & Freq. & $\%$ & \\
\hline 1 & Too many forms to fill & 72 & 60.0 & $7^{\text {th }}$ \\
\hline 2 & Late disbursement of loan & 82 & 68.3 & $5^{\text {th }}$ \\
\hline 3 & Long distance from house to loan source & 66 & 55.0 & $8^{\text {th }}$ \\
\hline 4 & High transport cost to and from loan source & 45 & 37.5 & $9^{\text {th }}$ \\
\hline 5 & Problem of getting guarantor & 88 & 73.3 & $4^{\text {th }}$ \\
\hline 6 & High interest rate & 90 & 75.0 & $3^{\text {rd }}$ \\
\hline 8 & Little or no supervision by loan officers & 36 & 30.0 & $10^{\text {th }}$ \\
\hline 9 & Problem of getting collateral & 92 & 76.7 & $2^{\text {nd }}$ \\
\hline 10 & Long period of processing loan applications & 99 & 82.5 & $1^{\text {st }}$ \\
\hline
\end{tabular}

Source: Field data, 2017.

Table 4 reveals the constraints that swamp rice farmers faced in accessing loan. In ranking order, the major constraints are long period of processing loan applications $(82.5 \%)$, problem of getting collateral $(76.7 \%)$ and high interest rate $(75 \%)$ while the minor constraints are long distance from house to loan source (55\%), high transport cost to and from loan source (37.5\%) and little or no supervision by loan officers $(30 \%)$ respectively. Long period of processing loan application always results in late disbursement of loan with concomitant effect of loan diversion and default. For effectiveness of formal loan administration in the study area, these factors need to be given due consideration.

\subsection{Constraints Faced by Rice Farmers in Rice Production in the Study Area}

The findings on the constraints to rice production by rice farmers in the study area are as presented in Table 5.

Table 5. Constraints faced by rice farmers in rice production in the study area.

\begin{tabular}{|c|c|c|c|c|}
\hline \multirow{2}{*}{$\mathbf{S} / \mathbf{N}$} & \multirow{2}{*}{ Constraints } & \multicolumn{2}{|l|}{ Yes } & \multirow{2}{*}{ Rank } \\
\hline & & Freq. & $\%$ & \\
\hline 1 & Inadequate farmland & 79 & 65.3 & $5^{\text {th }}$ \\
\hline 2 & Low yield as a result of poor soil & 82 & 68.3 & $3^{\text {rd }}$ \\
\hline 3 & Low yield as a result of pest and disease & 87 & 72.5 & $2^{\text {nd }}$ \\
\hline 4 & Low yield as a result of excess rainfall/drought & 67 & 55.8 & $10^{\text {th }}$ \\
\hline 5 & Difficulty in getting enough fertilizer to buy & 74 & 61.7 & $8^{\text {th }}$ \\
\hline 6 & Difficulty in getting enough seeds to buy & 75 & 62.5 & $7^{\text {th }}$ \\
\hline 8 & Crop destruction by cattle & 100 & 83.3 & $1^{\text {st }}$ \\
\hline 9 & Inadequate farmland for expansion & 79 & 65.3 & $5^{\text {th }}$ \\
\hline 10 & Unfavourable market price after harvesting & 81 & 67.5 & $4^{\text {th }}$ \\
\hline
\end{tabular}

Source: Field data, 2017.

Table 5 reveals that the major constraints that farmers faced swamp rice production in the study area. In ranking order, they are crop destruction by cattle $(83.3 \%)$, low yield as a result of pests and diseases $(72.5 \%)$ and low yield as a result of poor soil $(68.3 \%)$ while the minor constraints are difficulty in getting enough fertilizer to buy (61.7\%), high cost of fertilizer
(56.7\%) and low yield as a result of excess rainfall/drought $(55.8 \%)$. The problem of crop destruction by cattle has often resulted in clashes between the Fulani cattle herders and crop farmers across the country. This is because whenever the cattle graze the cropped farmland, the herders do not compensate the farmers for the damages on their crops. 


\section{Conclusion}

This study discovered that majority of the swamp rice farmers $(40 \%)$ applied for relatively large amounts (above $\$ 200,000.00$ ) but only $8 \%$ received loans above $\mathrm{N} 200,000.00$. More so, gender $\left(\mathrm{X}_{1}\right)$, farm income $\left(\mathrm{X}_{4}\right)$, household size $\left(\mathrm{X}_{5}\right)$, education $\left(\mathrm{X}_{6}\right)$ and collateral $\left(\mathrm{X}_{8}\right)$ positively increased the likelihood of farmers' access to loan at $1 \%$ significant level respectively while marital status $\left(\mathrm{X}_{3}\right)$, farming experience $\left(\mathrm{X}_{9}\right)$ and farm size $\left(\mathrm{X}_{7}\right)$ positively influence access to loan at $5 \%, 5 \%$ and $10 \%$ respectively. Only age $\left(\mathrm{X}_{2}\right)$ of farmers negatively influence access to loan at $5 \%$ significant level.

The major constraints farmers faced in accessing loan include long period of processing loan applications $(82.5 \%)$, problem of getting collateral $(76.7 \%)$ and high interest rate (75\%), Furthermore, major constraints faced by farmers in swamp rice production are crop destruction by cattle (83.3\%), low yield as a result of pests and diseases $(72.5 \%)$ and low yield as a result of poor soil (68.3\%).

\section{Recommendations}

In order to end the killings as a result of clashes between the cattle herders and crop farmers, the Federal Government should enact law that will motivate the cattle herders to compensate any farmer whose crops have been destroyed or eaten by cattle The State Government should make agrochemicals available to farmers at subsidized rate. Banks should process loan applications on time so that the loan will be disbursed to farmers at the appropriate time that the farmers will use it for farm operations. This would go a long way to reduce loan diversion and default among farmers.

\section{References}

[1] Adeyonu, A. G., Ajiboye, B. O., Isitor, S. U. and Faseyi, S. A. (2016) An analysis of the factors influencing access to credit by poultry farmers in Abuja, Nigeria. Proceedings of the $17^{\text {th }}$ Annual National Conference of Nigerian Association of Agricultural Economists (NAAE) held at Federal University of Technology Owerri $17^{\text {th }}-20^{\text {th }}$ Oct. 2016 pp 25.

[2] DBSA (2005). Development report 2005. Development Bank of South Africa (DBSA), Agriculture in South Africa Second Economy.

[3] Oladeebo, J. O and Oladeebo, O. E (2008). Determinants of loan repayment among smallholder farmers in Ogbomoso Agricultural Zone of Oyo State, Nigeria. Journal of Social Science. 17 (1): 59-62.

[4] Kuye, O. O (2016) Comparative analyses of beneficiaries and non-beneficiaries of bank loan among small-scale cassava farmers in South-South Nigeria (2009-2013). Unpublished $\mathrm{PhD}$ thesis submitted to the Department of Agricultural Economics, Management and Extension, Ebonyi State University, Abakaliki, Ebonyi State, Nigeria. pp 19-20.

[5] Murray, W. G (1994) Agricultural Finance: Principles and Practices of Farm Credit. Iowa State College Press, USA.
[6] Nwaru, J. C., Ubon, A. E. and Robert E. O. (2011). Determinants of Informal Credit Demand and Supply among Food Crop Farmers in Akwa Ibom State, Nigeria. Journal of Rural and Community Development: 1712-8277.

[7] Akudugu M. A. (2012). Estimation of the Determinants of Credit Demand by Farmers and Supply by Rural Banks in Ghana's Upper East Region. Asian Journal of Agriculture and Rural Development 2: 189-200.

[8] Diagne, A. and Zeller, M. (2001). Empirical measurements of household's access to credit and credit constraints in developing countries. Methodological Issues and Evidence, International Food Policy Research Institute, Washington DC.

[9] Echebiri, R. N. and Nwaogu, D. C. (2016) Determinants of credit access by rural farmers in Abia State, Nigeria. Proceedings of the $17^{\text {th }}$ Annual National Conference of Nigerian Association of Agricultural Economics held at Federal University of Technology, Owerri Oct.17-20, 2016. Pp 120-124.

[10] Dittoh, S. (2006). Effective Aid for Small Farmers in SubSaharan Africa: Southern Civil Society Perspective. Ghana Case Study.

[11] World Bank (2008) Finance for all? Policies and pitfalls in expanding access. World Bank Policy Research Report. The International Bank for Reconstruction and Development. Washington D. C.

[12] Mohammed, B. T, Achem, B, Abdulquadri, A. and Age, K. T, (2009) "Gender involvement in agricultural production" Proceedings of the $43^{\text {rd }}$ Annual Conference of the Agricultural Society of Nigeria, Abuja. 20- 25 October, 2004 pp 682-685.

[13] Spore (2007) "Family farming: The future of the world" CTA, The Netherlands No 131, October 2007. Pp 1.

[14] International Food Policy Research Institute (IFPRI) (2002) Women: The key to food security. Washington D. C, USA.

[15] World Bank (2001) Attacking Poverty: World Development Report 2000/2001. Poverty Alleviation. IFPRI, Policy Research Working Paper No 15 Washington D. C.

[16] Awotide, D. O and Akerele, E. O (2010) "Commercial agriculture in Nigeria: Prospects, social impacts, constraints and policy issues" Proceedings of the $11^{\text {th }}$ Annual National Conference of National Association of Agricultural Economists (NAAE) held at New Lecture Theatre, School of Agricultural Technology, Federal University of Technology, Minna. $30^{\text {th }}$ Nov- $3^{\text {rd }}$ Dec 2010 pp 1.

[17] Ugbajah, M. and Ugwumba, C. (2013). Analysis of Micro Credit as a Veritable Tool for Poverty Reduction among Rural Farmers in Anambra State, Nigeria. Discourse Journal of Agriculture and Food Sciences, 1 (10): 152-159.

[18] Kormawa, P., Okike, I., Okechukwu, R. and Akande, S. O. (2003). African Food Crisis - the Nigerian case study. Afrint project. Retrieved May 11, 2014 from http://blog.sam.lu.se/afrint/pdf/nigmicro.pdf.

[19] Adeniji, O. B. and Joshua, A. O. 2008. Evaluation of Loan Disbursement and Repayment of Supervised Credit Scheme of Nigeria Agricultural Cooperative and Rural Development Bank (NACRBD) in Zaria and Kaduna North Local Government Areas of Kaduna State, Nigeria. Journal of Agriculture and Social Research (JASR), 8 (2): 89-96. 
[20] National Population Commission (2006) National Population Commission 2006 Census Figure, Abuja, Federal Government of Nigeria.

[21] Anozie, R O., Ume, S I, Okelola, O E, Anozie, S N and Ubani, S I (2014) Determinant factors in loan disbursement to yam (Discorea Spp) farmers in Ehime Mbano, Imo State. A case study of Nsu Micro finance Bank, Taraba State. Journal of Agricultural Research. 3: 14-18.

[22] Oboh, V. U. and Ekpebu, I. D. (2011). Determinants of Formal Agricultural Credit Allocation to the Farm Sector by Arable Crop Farmers in Benue State, Nigeria. African Journal of Agricultural Research.6 (1), Pp. 181-185.
[23] Ameh, M. and Andrew, C. I. (2016) Socio-economic factors influencing agricultural loan acquisition among small-scale rice farmers in Benue State, Nigeria. Proceedings of the $17^{\text {th }}$ Annual National Conference of Nigerian Association of Agricultural Economists (NAAE) held at Federal University of Technology Owerri $17^{\text {th }}-20^{\text {th }}$ Oct. 2016 pp 91.

[24] Adebayo, C. O, Mohammed, U. S, Yisa, E, S and Beida, A. S (2016) Determinant of access to formal agricultural credit among small-scale cassava farmers in Kogi State, Nigeria. Book of Proceedings of the $17^{\text {th }}$ Annual National Conference of Nigerian Association of Agricultural Economists held in Michael Okpara Federal University of Agriculture, Umudike, Nigeria. Pp. 15-17. 